Earth Syst. Dynam. Discuss., doi:10.5194/esd-2016-76, 2017

Manuscript under review for journal Earth Syst. Dynam.

Published: 31 January 2017

(c) Author(s) 2017. CC-BY 3.0 License.

\title{
Inverse Gaussian distribution of wave set-up heights along a shoreline with complicated geometry
}

Tarmo Soomere ${ }^{1,2}$, Katri Pindsoo ${ }^{1}$

${ }^{1}$ Laboratory of Wave Engineering, Institute of Cybernetics at Tallinn University of Technology, Akadeemia tee 21, Tallinn, 5 12618, Estonia

${ }^{2}$ Estonian Academy of Sciences, Kohtu 6, Tallinn, 10130, Estonia

Correspondence to: Katri Pindsoo (katri.pindsoo@ioc.ee)

Abstract. The phenomenon of wave set-up may substantially contribute to the formation of devastating coastal flooding in certain coastal sections. We study empirical probability distribution of the occurrence of different set-up heights in section of coastline near Tallinn in the Gulf of Finland, the eastern Baltic Sea. The shoreline in the study area is often attacked by high waves from various directions and also has a complex geometry. Shown is that this distribution substantially deviates from the Rayleigh or the Weibull distribution that usually reflect the distribution of different wave heights. The distribution of wave set-up heights matches a Wald (inverse Gaussian) distribution along the entire study area. Even though different sections of the study area are open to different directions and host substantially different wave regimes, the leading term of

15 the exponent in the associated inverse Gaussian distribution varies insignificantly along the study area and generally is close to -1 . This appearance signals that extreme set-up events are substantially more probable that it could be expected from the probability of occurrence of severe seas. This feature is invariant with respect to the orientation of the coastline and with respect to the properties of local wave climate.

\section{Introduction}

20 The increase in the global sea level in current and projected marine climate change (Cazenave et al., 2014) is often associated with major consequences (Hallegatte et al., 2013) and economic damages to low-lying coastal areas (Darwin and Tol, 2001) that may lead to a loss of worldwide welfare of almost by $2 \%$ by the end of this century (Pycroft et al., 2016). This increase, however, contributes only a small fraction into the most devastating coastal floodings. These events, additionally to being economically extremely damaging (Meyer et al., 2013), may also lead to massive losses of lives and

25 desertification of entire coastal communities (Dube et al., 2009).

A devastating flooding is usually caused by the interplay of several drivers with fundamentally different predictability, physical, dynamical and statistical properties, and with different level of correlations between their contributions. For example, tides are almost perfectly regular and caused by extra-terrestrial drivers while a reasonable forecast of the impact of low atmospheric pressure (inverted barometric effect), wind-driven surge and wave-induced set-up requires a cluster of dedicated atmospheric, ocean circulation and wave models. The resulting high water levels may be additionally amplified by 
Earth Syst. Dynam. Discuss., doi:10.5194/esd-2016-76, 2017

Manuscript under review for journal Earth Syst. Dynam.

Published: 31 January 2017

(c) Author(s) 2017. CC-BY 3.0 License.

specific events and mechanisms such as tide-surge interactions (Batstone et al., 2013; Olbert et al., 2013), meteorologically driven long waves (Pattiarachi and Wijeratne, 2014; Pellikka et al., 2014; Vilibic et al., 2014) or seiches (Vilibic, 2006; Kulikov and Medvedev, 2013).

Along with contemporary numerical simulations and direct search for worst-case scenarios (e.g., Averkiev and Klevanny,

5 2010), the use of the probabilistic approach is a classic way to quantify the properties of extreme water levels and related risks. The relevant pool of literature contains substantial amount of work on both extreme water levels and their return periods (e.g., Purvis et al., 2008; Haigh et al., 2010; Arns et al., 2013) and on statistical parameters of water level variations (Serafin and Ruggiero, 2014; Fawcett and Walshaw, 2016). Similar probabilistic analysis has been extensively applied to average and extreme wave properties (e.g., Orimolade et al., 2016; Rueda et al., 2016), and properties of meteotsunamis

10 (Geist et al., 2014, Bechle et al., 2015). In most occasions the drivers of coastal floodings are neither completely independent nor completely dependent on each other. This feature generates the necessity to consider multivariate distributions of their properties. Most often, the simultaneous occurrence of storm surges and large waves is considered (e.g., Hawkes et al., 2002; Wadey et al., 2015; Rueda et al., 2016b); occasionally including also an analysis of joint distributions of wave heights, periods and directions (Masina et al., 2015).

15 Importantly, typical probability distributions of different contributors to extreme water levels may be fundamentally different. While the distribution of water levels is usually close to a Gaussian one (Bortot et al., 2000; Johansson et al., 2001; Mel and Lionello, 2014; Soomere et al., 2015), the probabilities of occurrence of different single wave heights are at best approximated either by a Rayleigh (Longuet-Higgins, 1952), Weibull (Forristall, 1978) or Tayfun distribution (SocquetJuglard et al., 2005). The empirical probabilities of average or significant wave heights in various offshore conditions usually

20 resemble either a Rayleigh or a Weibull distribution (Muraleedharan et al., 2007; Feng et al., 2014) while Pareto-type distributions are more suitable for the analysis of meteotsunami heights (Bechle et al., 2015). The total water level in semisheltered seas with extensive subtidal- or weekly-scale variability may contain two components, one of which has the classic quasi-Gaussian distribution whereas the other (storm surge) component has an exponential distribution and apparently mirrors a Poisson process (Soomere et al., 2015).

25 Wave-driven local water level set-up is one of the classic phenomena at open ocean coasts. It may often provide as much as $1 / 3$ of the total water level rise during a storm (Dean and Bender, 2006) and significantly contribute to extreme sea level events (Hoeke et al., 2013; Melet et al., 2016). Even though the physics of wave-set up (Longuet-Higgins and Stewart, 1964) is known for half a century, adequate parameterizations have been introduced (Stockdon et al., 2006) and many models take into account wave set-up to a certain extent (SWAN, 2007; Roland et al., 2009; Alari and Kõuts, 2012; Moghimi et al.,

30 2013), the contribution from this phenomenon apparently provides one of the largest uncertainties in modelling of storm surges and flooding (Dukhovskoy and Morey, 2011; Melet et al., 2013). This feature reflects the intrinsically complicated nature of the formation of this phenomenon. First of all, the set-up height strongly depends on the approach angle of waves at the actual breaker line. This angle is well-defined only if the coastline is almost straight, the nearshore is homogeneous in the alongshore direction and the wave field is monochromatic (Larson et al., 2010; Viška and Soomere, 2013; Lopez-Ruiz et 
Earth Syst. Dynam. Discuss., doi:10.5194/esd-2016-76, 2017

Manuscript under review for journal Earth Syst. Dynam.

Published: 31 January 2017

(c) Author(s) 2017. CC-BY 3.0 License.

al., 2014; 2015). Generally, this angle is a complicated function of shoreline geometry, nearshore bathymetry, wave properties and possibly increased water level. Even if the basic wave properties (height, period and propagation direction) are perfectly forecast or hindcast at some nearshore location, evaluation of the further propagation of waves over nearshore bathymetry is a major challenge because, e.g., refraction properties change along with the changes to the local water level.

5 Moreover, accurate wave hindcast and forecast are still a challenge in many water bodies and the outcome of modelling substantially depends on the used wind information (Nikolkina et al., 2014).

Several studies have focused on maxima of wave set-up over extended areas (O'Grady et al., 2015; Soomere et al., 2013) or the maxima of the contribution from wave set-up to water level extremes (Pindsoo and Soomere, 2016). This problem is relatively simple on comparatively straight open ocean coasts that are fairly homogeneous in the alongshore direction and

10 where the highest waves tend to approach the shore under relatively small angles. These features make it possible to use simplified schemes for evaluation of the impact of refraction and shoaling in the nearshore (e.g., Larson et al., 2010) or to assume that waves propagate directly onshore (O'Grady et al., 2015), and to reduce the problem to an evaluation of the properties of highest waves from a relatively narrow range of directions (Soomere et al., 2013). In areas with complicated geometry and especially in coastal segments where high waves may often approach under large angles to the shoreline it is

15 necessary to take into account full refraction and shoaling in the nearshore (Viška and Soomere, 2013; Pindsoo and Soomere, 2015).

Even though high storm surges are often associated with severe seas, the development of high set-up depends on many details. It does not necessarily reach its maximum level in the entire coastal section affected by a storm and in most occasions the maximum storm surge and maximum wave set-up do not occur simultaneously (Pindsoo and Soomere, 2015).

20 Moreover, it seems characteristic for coastal areas with complicated geometry that each short segment has its own 'perfect storm' that creates the all-highest sum of storm surge and wave set-up (Soomere et al., 2013).

These observations call for further analysis of the properties of the phenomenon of wave set-up. In this paper we focus on certain features of statistical distributions of set-up heights along an about $90 \mathrm{~km}$ long coastal section with complicated geometry and containing segments open towards fairly different directions. The goal is to identify the typical shapes of

25 distributions of simulated wave set-up heights and to analyse alongshore variability of these distributions. The test area is the vicinity of Tallinn Bay in the Gulf of Finland, the Baltic Sea.

The paper is organised as follows. Section 2 introduces the method of evaluation of maximum set-up height for obliquely approaching waves and provides a short overview of the simplified wave model for rapid evaluation of wave time series, the forcing data for this model and the procedure of evaluation of properties of breaking waves. Section 3 presents an analysis of

30 spatial variations of the extreme wave heights along the study area and estimates of the shape of empirical probability distribution of different set-up heights along the coast. This distribution substantially deviates from similar distributions of different wave conditions and exhibits unexpectedly large proportion of high set-up events. Several implications of the results are discussed in Section 4. 
Earth Syst. Dynam. Discuss., doi:10.5194/esd-2016-76, 2017

Manuscript under review for journal Earth Syst. Dynam.

Published: 31 January 2017

(c) Author(s) 2017. CC-BY 3.0 License.

\section{Methods and data}

\subsection{Set-up height for obliquely incident waves}

The classic concept of wave set-up (Longuet-Higgins and Stewart, 1962) relates the local increase in the water level with the onshore component of radiation stress. For small depth (incl. the area near the breaker line) the beaching waves can be described using the approximation of long waves and this component of radiation stress can be approximated as follows:

$$
S_{x x} \approx\left(\frac{1}{2}+\cos ^{2} \theta\right) E
$$

Here $S_{x x} \approx \cos \theta$ is the approach angle of waves with respect to onshore-directed normal to the shoreline, $E=\rho g H_{r m s} / 8=\rho g H_{S} / 8$ is the wave energy, $\rho$ is water density, $g$ is acceleration due to gravity, $H_{r m s}$ is the root mean square wave height and $H_{S}$ is the significant wave height. In ideal conditions of a plane impermeable beach the maximum set-up height for waves propagating directly onshore $(\theta=0)$ along a planar beach profile is (McDougal and Hudspeth, 1983)

$\bar{\eta}_{\max }=\frac{5}{16} \gamma_{b} H_{b}$

where $\gamma_{b}=d_{b} / H_{b}$ is the breaking index.

If waves approach under a nonzero angle $\theta$ with respect to the shore normal, the situation is much more complicated. Shi

15 and Kirby (2008) argue that the water level set-down at the breaker line is invariant with respect to the approach angle. The theoretical expression for the deviation $\eta$ of the water surface from the still level at a depth $d$ in the surf zone of an impermeable beach with parallel straight bottom is (Hsu et al., 2006; Shi and Kirby, 2008; the power at $\gamma_{b}$ in the first term at the right-hand side being corrected):

$$
\frac{\eta}{H_{b}}=\frac{\gamma_{b}^{2} \sin ^{2} \theta_{b}}{2\left(8+3 \gamma_{b}^{2}-2 \gamma_{b}^{2} \sin ^{2} \theta_{b}\right)}\left[\left(\frac{d}{H_{b}}\right)^{2}-1\right]-\frac{3 \gamma_{b}^{2}-2 \gamma_{b}^{2} \sin ^{2} \theta_{b}}{8+3 \gamma_{b}^{2}-2 \gamma_{b}^{2} \sin ^{2} \theta_{b}}\left(\frac{d}{H_{b}}-1\right)-\frac{\gamma_{b}^{2}}{16} .
$$

20 The last term at the right-hand side of Eq. (3) represents water level set-down at the breaker line, $H_{b}$ is the breaking wave depth and $\theta_{b}$ is the wave approach direction at breaking. The relative maximum set-up $\bar{\eta}_{\max }$, counted from this water level, occurs at a 'depth' $d=-\bar{\eta}_{\max }$ :

$$
\frac{\hat{\eta}_{\max }}{H_{b}}=\frac{\gamma_{b}^{2} \sin ^{2} \theta_{b}}{2\left(8+3 \gamma_{b}^{2}-2 \gamma_{b}^{2} \sin ^{2} \theta_{b}\right)}\left[\left(\frac{-\hat{\eta}_{\max }}{H_{b}}\right)^{2}-1\right]-\frac{3 \gamma_{b}^{2}-2 \gamma_{b}^{2} \sin ^{2} \theta_{b}}{8+3 \gamma_{b}^{2}-2 \gamma_{b}^{2} \sin ^{2} \theta_{b}}\left(\frac{-\hat{\eta}_{\max }}{H_{b}}-1\right) .
$$


Earth Syst. Dynam. Discuss., doi:10.5194/esd-2016-76, 2017

Manuscript under review for journal Earth Syst. Dynam.

Published: 31 January 2017

(c) Author(s) 2017. CC-BY 3.0 License.

For shore-normal waves the set-up with respect to the water level at the breaker line is $\hat{\eta}_{\max }=(3 / 8) \gamma_{b} H_{b}$ and the waterline is located at $\bar{\eta}_{\max }$ defined by Eq. (2). In the general case Eq. (4) is a quadratic equation with respect to $q=\hat{\eta}_{\max } / H_{b}$ :

$$
q=\frac{\gamma_{b}^{2} \sin ^{2} \theta_{b}}{2\left(8+3 \gamma_{b}^{2}-2 \gamma_{b}^{2} \sin ^{2} \theta_{b}\right)}\left(q^{2}-1\right)+\frac{3 \gamma_{b}^{2}-2 \gamma_{b}^{2} \sin ^{2} \theta_{b}}{8+3 \gamma_{b}^{2}-2 \gamma_{b}^{2} \sin ^{2} \theta_{b}}(q+1) .
$$

This equation can be rewritten as

$5 \gamma_{b}^{2} \sin ^{2} \theta_{b} q^{2}-16 q+6 \gamma_{b}^{2}-5 \gamma_{b}^{2} \sin ^{2} \theta_{b}=0$

and has two positive solutions for physically reasonable values $0<\gamma_{b} \leq 2$. As for very small incidence angles $\theta_{b} \approx 0$ the physically relevant solution must be bounded (almost equal to $q \approx 3 \gamma_{b}^{2} / 8$ ), the expression

$$
q_{1}=\frac{16-\sqrt{256-4 \gamma_{b}^{2} \sin ^{2} \theta_{b}\left(6 \gamma_{b}^{2}-5 \gamma_{b}^{2} \sin ^{2} \theta_{b}\right)}}{2 \gamma_{b}^{2} \sin ^{2} \theta_{b}}
$$

provides the necessary solution. Eq. (7) deviates from a similar expression (30) of Hsu et al. (2006) by reasons discussed by

10 Shi and Kirby (2008). The maximum set-up height is thus

$$
\bar{\eta}_{\max }=\left(q_{1}-\frac{\gamma_{b}^{2}}{16}\right) H_{b}
$$

\subsection{Wave time series in along the nearshore of the study area}

We evaluate the shape and parameters of statistical distribution set-up heights along an about $80 \mathrm{~km}$ long coastal segment of Tallinn Bay and Muuga Bay (Fig. 1). The study area is an example of a wave-dominated micro-tidal region. The shoreline of

15 this section of the northern shore of Estonia at the coast of the Gulf of Finland in the north-western Baltic Sea is locally almost straight (for scales up to a kilometre or two). Several relatively straight parts at Suurupi Peninsula and the area of Saviranna are open to the north. However, on larger scales (from a few kilometres) the coast contains large peninsulas and bays deeply cut into the mainland. The shores of these landforms are open to various directions. As the formation of wave set-up crucially depends on the wave height and the attack angle, this type of coastal landscape makes it possible to involve coastal sections with radically different magnitudes of set-up (see "climatology" of set-up heights in this area in Soomere et al., 2013).

The fetch length in the Gulf of Finland is $>200 \mathrm{~km}$ for western and eastern winds but is generally below $100 \mathrm{~km}$ for all other wind directions. The all-time highest significant wave heights in the Gulf of Finland just a few tens of km to the north of the study area have exceeded $5.2 \mathrm{~m}$ (Tuomi et al., 2011). Strong north-north-western storms may generate significant wave 25 heights $>4 \mathrm{~m}$ in the interior of Tallinn Bay (Soomere, 2005). The predominant strong wind directions in this region are 
Earth Syst. Dynam. Discuss., doi:10.5194/esd-2016-76, 2017

Manuscript under review for journal Earth Syst. Dynam.

Published: 31 January 2017

(c) Author(s) 2017. CC-BY 3.0 License.

south-west and north-north-west. Eastern storms are less frequent but may generate as high waves as the western storms (Soomere et al., 2008). The varying mutual orientation of high winds and waves and the shoreline sections thus makes it possible to analyse potential variations in the distributions of set-up heights.

We employ time series of wave properties (significant wave height, wave period and propagation direction) reconstructed

5 using the wave model WAM and one-point high-quality wind information from the vicinity of the study area for 1981-2016. The wave model is set-up in a triple nested version with the resolution of the innermost grid about $470 \mathrm{~m}$ (Soomere, 2005). Following the experience of using this model in the Baltic Sea and Finnish archipelago conditions (where it is important to adequately represent the wave growth in low wind and short fetch conditions) (Tuomi et al., 2011; 2012), the model uses an increased frequency range of waves up to $2.08 \mathrm{~Hz}$. The ignoring of the presence of sea ice may lead to a certain

10 overestimation of the overall wave energy in the region but apparently does not significantly distort the shape of distributions of set-up heights and the variation of these distributions along the shoreline.

The model is implemented using a simplified scheme for rapid reconstructions of long-term wave statistics. Wave computations are speeded up by replacing long-term calculations of the sea state by an analysis precomputed maps of wave properties. This simplification relies on a favourable feature of the study area. Namely, wave fields rapidly become saturated

15 and have relatively short memory in the study area (Soomere, 2005). Consequently, a reasonable reproduction of wave statistics is possible by assumption that an instant wave field in Tallinn Bay is a function of a short section of the wind dynamics. This assumption justifies the splitting of the calculations into a number of short independent sections with a duration of 3-12 hours. As details of the particular model set-up, the used bathymetry, the implementation, and validations of the model outcome have been repeatedly discussed, the reader is referred to (Soomere, 2005; Soomere et al., 2013) for

20 further information.

The described approach, however, makes it possible to circumvent one of the major issues of replication of the Baltic Sea wave fields, namely, the problems with quality and frequent inconsistency of modelled wind data sets (Nikolkina et al., 2014). The quality of wave hindcast primarily depends on the adequacy of the wind information. In particular, wave set-up is intrinsically very sensitive with respect to the wave propagation direction. It is therefore crucial to force the wave model with correct information about wind directions. This is an issue in the Gulf of Finland because atmospheric models often fail to reproduce wind directions in this water body (Keevallik and Soomere, 2010). To overcome this issue, we use wind data from an offshore location in the central part of this gulf. The wind recordings at Kalbådagrund $\left(59^{\circ} 59^{\prime} \mathrm{N}, 25^{\circ} 36^{\prime} \mathrm{E}\right.$, a caisson lighthouse located on the top of a shoal far offshore) are known to impeccably represent marine wind properties. Even though this site is located at a distance of some $60 \mathrm{~km}$ from the study area, it is expected to correctly record wind properties

30 in the offshore that are mostly responsible for the generation of surface waves.

The entire simulation interval 1981-2016 contained 103498 wind measurement instants with a time step of $3 \mathrm{~h}$. As this resolution of wind measurements was employed for more than two decades, we selected analogous data also from the newer higher-resolution recordings. In about 9000 cases (less than 10\%) either wind speed or direction was missing. These time 
Earth Syst. Dynam. Discuss., doi:10.5194/esd-2016-76, 2017

Manuscript under review for journal Earth Syst. Dynam.

Published: 31 January 2017

(c) Author(s) 2017. CC-BY 3.0 License.

instants were excluded from the further analysis. As some of these instants involved quite strong winds, the analysis may underestimate the highest wave set-up events.

\subsection{Nearshore refraction and shoaling}

The nearshore grid cells selected for the analysis (Fig. 1) are located in at least $4 \mathrm{~m}$ deep area in order to avoid massive wave

5 breaking already at the formal calculation location. Some of the cells are located in even deeper locations with water depth 20-27 m. The presence of various underwater features and inhomogeneities in the study area means that shoaling and refraction may considerably impact the wave fields even along the relatively short routes (normally about $1 \mathrm{~km}$ ) from the model grid cell until the breaking line. As the predominant storm directions are the south-east, north-north-west and east, in most occasions high waves approach some of the selected grid cells under large angles with respect to the shore normal.

10 Therefore, it is not acceptable to assume that the incidence angles are small and simplified approaches to replicate the changes in the immediate nearshore (Lopez-Ruiz et al., 2014; 2015) and even advanced approximations (Hansen and Larson, 2010) may fail. For this reason we calculate the joint impact of shoaling and refraction of approaching waves in the framework of the linear wave theory (Viška and Soomere, 2013; Soomere et al., 2013).

As usual, it is assumed that the numerically evaluated wave field for each time instant is monochromatic and characterised

15 by the numerically simulated significant wave height $H_{0}$, peak period and mean approach direction $\theta_{b}$ (with respect to the onshore-directed normal to the shoreline) that are evaluated at the centre of each selected grid cell. Similarly, it is assumed that the nearshore seabed is plane with isobaths strictly parallel to the shoreline and that breaking waves are long waves. Then the wave height $H_{b}$ at the breaking line can be found as the smaller real solution of the following algebraic equation of 6th order (Viška and Soomere, 2013; Soomere et al., 2013):

$20 \frac{H_{b}^{5} g}{H_{0}^{4} \gamma_{b}}\left(1-\frac{g H_{b}}{\gamma_{b}} \frac{\sin ^{2} \theta_{0}}{c_{f 0}^{2}}\right)=c_{g 0}^{2}\left(1-\sin ^{2} \theta_{0}\right)$.

Here $c_{g}$ is the group speed, $c_{f}$ is the phase speed and the subscripts " 0 " and " $b$ " indicate the relevant value at the particular wave model grid cell and at the breaker line, respectively. The set of assumptions is completed with the common notion that the breaking index is $\gamma_{b}=H_{b} / d_{b}=0.8$.

Several earlier studies of extreme wave set-up heights (Soomere et al., 2013; Pindsoo and Soomere, 2015) have taken into

25 account only waves that approach the coast under angles $\pm 15^{\circ}$ with respect to the shore normal. This assumption is evidently valid at the open ocean coasts where waves usually approach the shore under relatively small angles. However, in specific conditions of semi-sheltered basins with short fetch and with several strong wind directions, this assumption may become unusable. To evaluate its applicability and to estimate distortions to the distributions of different set-up heights, we repeated calculations based on this selection of wave fields. 
Earth Syst. Dynam. Discuss., doi:10.5194/esd-2016-76, 2017

Manuscript under review for journal Earth Syst. Dynam.

Published: 31 January 2017

(c) Author(s) 2017. CC-BY 3.0 License.

\section{Results}

\subsection{Maximum set-up heights}

The phenomenon of wave set-up is only meaningful if large waves are propagation from the open sea towards the shore. Differently from open ocean coasts where swells always create certain set-up, in sheltered sea areas with complicated

5 geometry swells may be infrequent and wind waves often propagate from the nearshore towards the open sea. Wind regime of the study area consists of superposition of four relatively frequent wind systems (Soomere et al., 2008). The most frequent wind direction here is from the south-west (that is, from the mainland to the sea). Still, the proportion of wave systems with the average propagation to the onshore is about 60\% (Fig. 2). The only exception is grid cell 107 (Fig. 1) between Viimsi Peninsula and the island of Aegna that is sheltered for almost all directions. The statistical properties of wave set-up phenomena discussed below thus represent 40,000-70,000 examples of wave fields for all other cells.

We start from a comparison of maximum set-up heights evaluated using the above-described approach and a simpler method (Soomere et al., 2013) that took into account wave fields that propagated almost directly onshore $\left( \pm 15^{\circ}\right.$ with respect to the shore normal). The two methods lead to comparable results for all coastal segments that are relatively open to the Gulf of Finland (Fig. 3). As expected, the simplified method gives systematically higher results for coastal segments that are

15 relatively open to the Gulf of Finland (Fig. 3). The differences in the maximum set-up heights are mostly close to $0.2-0.3 \mathrm{~m}$, but in some occasion just a few $\mathrm{cm}$. The largest maxima are relatively different.

The two methods give different estimates also for the sheltered areas and particularly for 'side' sections of deeply cut bays (that is, sections to which waves approach under a relatively large angle). Interestingly, estimates using the method that fully calculates the radiation stress are remarkably higher in these sections than those with the simplified method (that tends to

20 give higher values in all other areas). This difference indicates that the impact of refraction is substantial. It is thus likely that refraction may redirect waves so that beaches that even seemingly well sheltered geometrically may at times receive remarkable amounts of wave energy. In other words, the impact of refraction often overrides here the effect of geometric blocking of waves by changing orientation of the coastline (cf Caliskan and Valle-Levinson, 2008).

The maximum differences in set-up heights for such (seemingly geometrically sheltered) sections are often $0.2-0.3 \mathrm{~m}$ and

25 reach up to $0.6 \mathrm{~cm}$ in a few occasions. Such a strong impact of refraction is not usual but also not unique in coastal areas. It is usually thought to be responsible for a local increase in wave heights not only in the Baltic Sea (Soomere, 2003) but also in extreme ocean conditions (Babanin et al., 2011). The major differences in the two sets of estimates of set-up heights clearly signal that the use of simplified methods and taking into account only waves that propagate almost onshore may lead to substantial underestimation of various wave-driven hazards.

30 Notice that some differences of the latter set of results from those presented in (Soomere et al., 2013; Pindsoo and Soomere, 2015) stem from the different time periods used in the calculations. Simulations for 1981-2010 indicate that the maximum set-up heights in coastal areas open to the east were mostly created in the 1980s (Soomere et al., 2013) even though the 
Earth Syst. Dynam. Discuss., doi:10.5194/esd-2016-76, 2017

Manuscript under review for journal Earth Syst. Dynam.

Published: 31 January 2017

(c) Author(s) 2017. CC-BY 3.0 License.

maximum wave heights occurred starting from the mid-1990s. This feature may be related to a change in the strong wind directions so that eastern storms became weaker.

However, there is increasing evidence that this process has reversed and strong eastern storms have returned to the area. The first evidence of this change is the that the all-time highest significant wave height $5.2 \mathrm{~m}$ was recorded in the Gulf of Finland

5 for the second time during an extreme eastern storm on 29-30 November 2012 (Pettersson et al., 2013). Pindsoo and Soomere (2015) observed that many new all-time highest set-up events apparently occurred in locations open to the east. This process evidently continues and has led to generation of all-highest simulated waves in a number of locations at the eastern Viimsi Peninsula near Leppneeme (Fig. 4).

\subsection{Frequency of occurrence of set-up heights}

10 Somewhat surprisingly, the empirical distributions of occurrence of set-up heights are clearly non-Gaussian in all locations of the study area (Fig. 5). Even though the replication of wave propagation directions by the wave model and the impact of refraction may suffer from insufficient resolution of both the wind information and wave model, the presented distributions exhibit a similar shape for the entire study area. Their appearance clearly differs from all usual distributions of the magnitude of wave phenomena such as the classic (Rayleigh) distribution of single wave heights (Longuet-Higgins, 1952), Tayfun

15 distribution of the heights of largest waves, the Weibull family of distributions for the occurrence of various wave conditions, or the Rayleigh distribution for run-up of (narrow-banded) Gaussian wave fields (Didenkulova et al., 2008). Therefore, none of these distributions can be used for the approximation of wave set-up heights.

Also, as the appearance of distributions of set-up heights in log-linear coordinates is clearly concave upwards along the entire study area, even the exponential distribution (that describes, e.g., storm surges in the study area, Soomere et al., 2015)

20 is not suitable for their description. This appearance suggests that the background process is not a Poisson one (that would lead to basically linear shape of the distribution in question in log-linear coordinates). Importantly, this concave-up appearance of the distributions of set-up heights means that very large set-up events are systematically much higher and/or occur much more frequently than similar events of highest storm surges.

To further explore the shape of the distributions of set-up height and its possible variations along the shoreline we assume

25 that these distributions belong to the family of general exponential distributions. The overall appearance of these empirical distributions in log-linear coordinates suggests that their shape can be, as a first approximation, matched with a quadratic polynomial $a p^{2}+b p+c$. The values of the coefficient $a$ at the leading term are exclusively negative and predominantly close to -1 in the entire study area (Fig. 6). The absolute values of this parameter are clearly larger than 1 only along the eastern coast of several bays deeply cut into mainland (Tallinn Bay, Jõesuu Bay) and in one location of the interior of Kopli

30 Bay (Fig. 1). This feature indicates that the relevant distribution is close to the classic inverse Gaussian (Wald) distribution. and its basic shape is (Folks and Chikara, 1978)

$$
P \sim \exp \left(-p^{2}\right)
$$


Earth Syst. Dynam. Discuss., doi:10.5194/esd-2016-76, 2017

Manuscript under review for journal Earth Syst. Dynam.

Published: 31 January 2017

(c) Author(s) 2017. CC-BY 3.0 License.

Interestingly, the coefficient $a$ at the leading term of the approximating polynomial varies insignificantly along the study area. More importantly, its variations are uncorrelated with the values of maximum set-up heights along the study area. This feature signals that the basic features of the distribution in question are invariant with respect to the properties of local wave climate, incl. the shape of the relevant Weibull distribution for different wave conditions (that largely varies along the study

5 area as shown in Soomere, 2005). This conjecture is supported by comparatively small variations of the values of other parameters in the polynomial approximation (Fig. 6b,c). The values of $b$ are all positive and mostly in the range of $2-4$. The values of parameter $c$ are typically positive and between 0 and 3; however, a few negative and even larger positive values occur in single cells.

\section{Discussion}

10 The performed analysis first of all reveals that numerical estimates of maxima of wave set-up heights are relatively sensitive with respect to the particular way of evaluation of the impact of radiation stress and the transformation of wave properties in the nearshore. The magnitude of the related effects substantially depends on the appearance of bathymetry. The impact of refraction can easily override the purely geometric effects of shoreline orientation changes and redirect substantial levels of wave energy into seemingly sheltered shore sections. This feature calls for the necessity of using high-resolution information

15 about wind (incl. wind directions) and bathymetry together with advance methods for the evaluation of propagation and impact of radiation stress in the nearshore in operational and hindcast models of coastal flooding.

The core message of the analysis is that the basic shape of probability distribution function of different set-up heights is concave upwards in log-linear plot. The appearance of this distribution varies insignificantly along the study area. As this area contains a variety of sections open to different directions and with radically different wave properties, the qualitative

20 shape in question is basically invariant with respect to the properties of local wave climate.

Further, the empirical distributions of wave set-up heights can be adequately approximated with a family of exponential distributions $P \sim \exp \left(-p^{2}\right)$ with a negative coefficient at the quadratic approximation of the exponent. The relevant distributions are known as inverse Gaussian (Wald) distributions. Interestingly, the coefficient at the leading term of such a quadratic approximation is close to -1 and varies insignificantly along the entire study area (Fig. 6a). This feature once more

25 confirms that the established distribution is universal for wave set-up heights even though its details may obviously depend on local conditions. As the coefficient at the linear term of this quadratic approximation is clearly nonzero (Fig. 6b), the distribution in question does not reduce to a Lévy distribution.

This result is intriguing because sensible approximations of inverse Gaussian (Wald) distributions are scarce in descriptions of geophysical phenomena. Perhaps the most well-known example of the use of a Wald distribution is to describe the time a

30 Brownian motion (with positive drift) takes to reach a fixed positive level. Other examples include statistical properties of soil phosphorus (Manunta et al., 2002), long-distance seed dispersal by wind (Katul et al., 2005) or some models of failure (Park and Padgett, 2005). 
Earth Syst. Dynam. Discuss., doi:10.5194/esd-2016-76, 2017

Manuscript under review for journal Earth Syst. Dynam.

Published: 31 January 2017

(c) Author(s) 2017. CC-BY 3.0 License.

An obvious implication from the match of statistics of set-up heights with an inverse Gaussian distribution is that extreme set-up events may be much more frequent than their estimates based on classic Gaussian statistics and also clearly more frequent than similar estimates for Poisson processes. This increase in probability of large wave set-up events is balanced by a similar decrease of events with an average magnitude compared to normally distributed events. The described features

5 indicate that the role of extreme wave set-up events in floodings (and their contribution to associated damages and economic losses) may be considerably larger than expected based on classic Gaussian (or Weibull) statistics.

\section{Acknowledgements}

The research was partially supported by the institutional support of the Estonian Ministry of Education and Research (IUT33-3), by the project "Sebastian Checkpoints - Lot 3 Baltic" of the call MARE/2014/09 and by the ERA-NET Rus+ network EXOSYSTEM.

\section{References}

Alari, V. and Kõuts, T.: Simulating wave-surge interaction in a non-tidal bay during cyclone Gudrun in January 2005. In Proceedings of the IEEE/OES Baltic 2012 International Symposium "Ocean: Past, Present and Future. Climate Change Research, Ocean Observation \& Advanced Technologies for Regional Sustainability, " May 8-11, Klaipeda, Lithuania. IEEE

15 Conference Publications, doi: 10.1109/ BALTIC.2012.6249185, 2012.

Arns, A., Wahl, T., Haigh, I. D., Jensen, J., and Pattiaratchi, C.: Estimating extreme water level probabilities: A comparison of the direct methods and recommendations for best practise, Coast. Eng., 81, 51-66, doi: 10.1016/j.coastaleng.2013.07.003, 2013.

Averkiev, A. S. and Klevanny, K. A.: A case study of the impact of cyclonic trajectories on sea-level extremes in the Gulf of 20 Finland, Cont. Shelf Res., 30, 707-714, 2010.

Babanin, A. V., Hsu, T.-W., Roland, A., Ou, S.-H., Doong, D.-J., and Kao, C. C.: Spectral wave modelling of Typhoon Krosa, Nat. Hazards Earth Syst. Sci., 11, 501-511, doi: 10.5194/nhess-11-501-2011, 2011.

Batstone, C., Lawless, M., Tawn, J., Horsburgh, K., Blackman, D., McMillan, A., Worth, D., Laeger, S., and Hunt, T.: A UK best-practice approach for extreme sea-level analysis along complex topographic coastlines, Ocean Eng., 71, 28-39, 2013.

25 Bechle, A. J., Kristovich, D. A. R., and Wu, C. H.: Meteotsunami occurrences and causes in Lake Michigan, J. Geophys. Res-Oceans, 120, 8422-8438, doi: 10.1002/2015JC011317, 2015.

Bortot, P., Coles, S., and Tawn, J.: The multivariate Gaussian tail model: an application to oceanographic data. J. Roy. Stat. Soc. A-Appl. Stat. 49, 31-49, doi: 10.1111/1467-9876.00177, 2000. 
Earth Syst. Dynam. Discuss., doi:10.5194/esd-2016-76, 2017

Manuscript under review for journal Earth Syst. Dynam.

Published: 31 January 2017

(c) Author(s) 2017. CC-BY 3.0 License.

Caliskan, H., Valle-Levinson, A.: Wind-wave transformations in an elongated bay. Cont. Shelf Res., 28, 1702-1710, doi: 10.1016/j.csr.2008.03.009, 2008.

Cazenave, A., Dieng B., Meyssignac, B., von Schuckmann, K., Decharme, B., and Berthier, E.: The rate of sea-level rise, Nat. Clim. Change, 4, 358-361, doi:10.1038/nclimate2159, 2014.

5 Darwin, R.F. and Tol, R.S.J.: Estimates of the economic effects of sea level rise, Environ. Resource Ecnomics, 19, 113-129, doi: 0.1023/A:1011136417375, 2001.

Dean, R. G. and Bender, C. J.: Static wave set-up with emphasis on damping effects by vegetation and bottom friction, Coast. Eng., 53, 149-165, 2006.

Didenkulova, I., Pelinovsky, E., and Sergeeva, A.: Statistical characteristics of long waves nearshore. Coast. Eng. 58, 94-

10 102, doi: 10.1016/j.coastaleng.2010.08.005, 2008.

Dube, S. K., Jain, I., Rao, A. D., and Murty, T. S.: Storm surge modelling for the Bay of Bengal and Arabian Sea, Nat. Hazards, 51, 3-27, doi: 10.1007/s11069-009-9397-9, 2009.

Dukhovskoy, D. S. and Morey, S. L.: Simulation of the Hurricane Dennis storm surge and considerations for vertical resolution, Nat. Hazards, 58, 511-540, doi: 10.1007/s11069-010-9684-5, 2011.

15 Fawcett, L., Walshaw, D.: Sea-surge and wind speed extremes: optimal estimation strategies for planners and engineers, Stoch Environ Res Risk Assess, 30:463-480, DOI 10.1007/s00477-015-1132-3, 2016.

Feng, X., Tsimplis, M. N., Quartly, G. D., and Yelland, M. J.: Wave height analysis from 10 years of observations in the Norwegian Sea. Cont Shelf Res 72, 47-56, doi: 10.1016/j.csr.2013.10.013Forristall, GZ 1978. Statistical distribution of wave heights in a storm, J. Geophys. Res-Oceans, 83(NC5), 2353-2358, 2014.

20 Folks, J. L. and Chikara, R. S.: The inverse Gaussian distribution and its statistical application--A Review. J. R. Stat. Soc. Ser. B-Methodol 40, 263-289, doi: 10.2307/2984691, 1978.

Geist, E. L., ten Brink, U. S., and Gove, M.: A framework for the probabilistic analysis of meteotsunamis, Nat. Hazards, 74, 123-142, doi: 10.1007/s11069-014-1294-1, 2014.

Hallegatte, S., Green, C., Nicholls, R. J., and Corfee-Morlot, J.: Future flood losses in major coastal cities, Nat. Clim. 25 Change, 3, 802-806, 2013.

Hawkes, P. J., Gouldby, B. R., Tawn, J. A., and Owen, M. W.: The joint probability of waves and water levels in coastal engineering design, J. Hydraulic Res., 40, 241-251, 2002.

Haigh, I. D., Nicholls, R., and Wells, N.: A comparison of the main methods for estimating probabilities of extreme still water levels, Coast. Eng., 57, 838-849, 2010.

30 Hoeke, R. K., McInnes, K. L., Kruger, J. C., McNaught, R. J., Hunter, J. R., and Smithers, S. G. Widespread inundation of Pacific islands triggered by distant-source wind-waves, Glob. Planet Chang., 108, 128-138, 2013. 
Earth Syst. Dynam. Discuss., doi:10.5194/esd-2016-76, 2017

Manuscript under review for journal Earth Syst. Dynam.

Published: 31 January 2017

(c) Author(s) 2017. CC-BY 3.0 License.

Hsu, T.-W., Hsu, J. R.-C., Weng, W.-K., Wang, S.-K., and Ou, S.-H.: Wave setup and setdown generated by obliquely incident waves, Coast. Eng., 53, 865-877, 2006.

Johansson, M., Boman, H., Kahma, K., and Launiainen, J.: Trends in sea level variability in the Baltic Sea, Boreal Environ. Res. 6, 159-179, 2001.

5 Katul, G. G., Porporato, A., Nathan, R., Siqueira, M., Soons, M. B., Poggi, D., Horn, H. S., and Levin, S. A.: Mechanistic analytical models for long-distance seed dispersal by wind, American Naturalist, 166, 368-381, doi: 10.1086/432589, 2005.

Keevallik, S. and Soomere, T.: Towards quantifying variations in wind parameters across the Gulf of Finland, Estonian J. Earth Sci., 59, 288-297, 2010.

Kulikov, E. A. and Medvedev, I. P.: Variability of the Baltic Sea level and floods in the Gulf of Finland, Oceanology, 53, 10 145-151, doi: 10.1134/S0001437013020094, 2013.

Larson, M., Hoan, L. X., and Hanson, H.: Direct formula to compute wave height and angle at incipient breaking, J. Waterw. Port C-ASCE., 136, 119-122, doi: 10.1061/ASCEWW.1943-5460.0000030, 2010.

Longuet-Higgins, M. S.: On the statistical distribution of the heights of sea waves, J. Mar. Res., 11, 1245-1266, 1952.

Longuet-Higgins, M. S. and Stewart, R. W.: Radiation stress and mass transport in gravity waves with application to "surf-

15 beats", J. Fluid Mech., 8, 565-583, 1962.

Longuet-Higgins, M. S., Stewart, R. W.: Radiation stresses in water waves: a physical discussion with applications, DeepSea Res., 11, 529-562, 1964.

Lopez-Ruiz, A., Ortega-Sanchez, M., Baquerizo, A., and Losada, M. A.: A note on alongshore sediment transport on weakly curvilinear coasts and its implications, Coast. Eng., 88, 143-153, doi: 10.1016/j.coastaleng.2014.03.001, 2014.

20 Lopez-Ruiz, A., Solari, S., Ortega-Sanchez, M., and Losada, M.: A simple approximation for wave refraction - Application to the assessment of the nearshore wave directionality, Ocean Modelling, 96 324-333, doi: 10.1016/j.ocemod.2015.09.007, 2015.

Manunta, P., Feng, Y., Goddard, T., Anderson, A. M., and Cannon, K.: Analysis of soil test phosphorus to assess the risk of P transport in a watershed. Comm. Soil Sci. Pland Analysis, 33, 3481-3492, doi: 10.1081/CSS-12001452, 2002.

25 McDougal, W. G., Hudspeth, R. T.: Wave setup/setdown and longshore current on non-planar beaches, Coast. Eng., 7, 103117, 1983.

Masina, M., Lamberti, A., and Archetti, R.: Coastal flooding: A copula based approach for estimating the joint probability of water levels and waves, Coast. Eng., 97, 37-52, doi: 10.1016/j.coastaleng.2014.12.010, 2015.

Mel, R. and Lionello, P.: Verification of an ensemble prediction system for storm surge forecast in the Adriatic Sea, Ocean

Dyn., 64, 1803-2814. doi:10.1007/s10236-014-0782-x, 2014. 
Earth Syst. Dynam. Discuss., doi:10.5194/esd-2016-76, 2017

Manuscript under review for journal Earth Syst. Dynam.

Published: 31 January 2017

(c) Author(s) 2017. CC-BY 3.0 License.

Melet, A., Almar, R., and Meyssignac, B.: What dominates sea level at the coast: a case study for the Gulf of Guinea, Ocean Dyn., 66, 623-636, doi: 10.1007/s10236-016-0942-2, 2016.

Meyer, V., Becker, N., Markantonis, V.,; Schwarze, R., van den Bergh, J.C.J.M., Bouwer, L.M., Bubeck, P., Ciavola, P., Genovese, E., Green, C., Hallegatte, S., Kreibich, H., Lequeux, Q., Logar, I., Papyrakis, E., Pfurtscheller, C., Poussin, J., 5 Przyluski, V., Thieken, A.H., and Viavattene, C. Review article: Assessing the costs of natural hazards - state of the art and knowledge gaps, Nat. Hazards Earth Syst. Sci., 13, 1351-1373, doi: 10.5194/nhess-13-1351-2013, 2013.

Moghimi, S., Klingbeil, K., Gräwe, U., and Burchard, H.: A direct comparison of a depth-dependent Radiation stress formulation and a Vortex force formulation within a three-dimensional coastal ocean model, Ocean Modell., 70, 132-144, http://dx.doi.org/10.1016/j.ocemod.2012.10.002, 2013.

10 Muraleedharan, G., Rao, A.D., Kurup, P.G., Nair, N.U., and Sinha, M.: Modified Weibull distribution for maximum and significant wave height simulation and prediction, Coast. Eng. 54, 630-638, doi: 10.1016/j.coastaleng.2007.05.001, 2007.

Nikolkina, I., Soomere, T., and Räämet, A.: Multidecadal ensemble hindcast of wave fields in the Baltic Sea. In: The 6th IEEE/OES Baltic Symposium Measuring and Modeling of Multi-Scale Interactions in the Marine Environment, May 26-29, Tallinn Estonia. IEEE Conference Publications, 9 pp., doi: 10.1109/BALTIC.2014.6887854, 2014.

15 O’Grady, J.G., McInnes, K.L., and Hoeke, R.K.: Forecasting maximum wave setup hazards around Australia. Coasts \& Ports Conference 2015, 15-18 September 2015, Pullman Hotel, Auckland, 636-641, 2015.

Olbert, A.I., Nash, S., Cunnane, C., and Hartnett, M.: Tide-surge interactions and their effects on total sea levels in Irish coastal waters, Ocean Dyn., 63, 599-614, 2013.

Orimolade, A. P., Haver, S., and Gudmestad, O. T.: Estimation of extreme significant wave heights and the associated

20 uncertainties: A case study using NORA10 hindcast data for the Barents Sea, Marine Structures 49. 1e17, http://dx.doi.org/10.1016/j.marstruc.2016.05.004, 2016.

Park, C. and Padgett, W.J.: Accelerated degradation models for failure based on geometric Brownian motion and gamma processes, Lifetime Data Anal., 11, 511-527, doi: 10.1007/s10985-005-5237-8, 2005.

Pattiaratchi, C. and Wijeratne, E. M. S.: Observations of meteorological tsunamis along the south-west Australian coast, Nat.

25 Hazards, 74, 281-303, 2014.

Pellikka, H., Rauhala, J., Kahma, K.K., Stipa, T., Boman, H., and Kangas, A.: Recent observations of meteotsunamis on the Finnish coast, Nat. Hazards, 74, 197-215, doi: 10.1007/s11069-014-1150-3, 2014.

Pettersson, H., Lindow, H., and Brüning, T.: Wave climate in the Baltic Sea 2012. HELCOM Baltic Sea Environment Fact Sheets 2012. http:/helcom.fi/baltic-sea-trends/environment-fact-sheets/hydrography/wave-climate-in-the-baltic-sea/, 2013.

30 Pindsoo, K. and Soomere, T.: Contribution of wave set-up into the total water level in the Tallinn area, Proc. Estonian Acad. Sci., 64(3S), 338-348, doi: 10.3176/proc.2015.3S.03, 2015. 
Earth Syst. Dynam. Discuss., doi:10.5194/esd-2016-76, 2017

Manuscript under review for journal Earth Syst. Dynam.

Published: 31 January 2017

(c) Author(s) 2017. CC-BY 3.0 License.

Purvis, M. J., Bates, P. D., and Hayes, C. M.: A probabilistic methodology to estimate future coastal flood risk due to sea level rise, Coast. Eng. 55, 1062-1073, doi: 10.1016/j.coastaleng.2008.04.008, 2008.

Pycroft, J., Abrell, J., and Ciscar, J. C.: The Global Impacts of Extreme Sea-Level Rise: A Comprehensive Economic Assessment, Environ. Resource Ecnomics, 64, 225-253, doi: 10.1007/s10640-014-9866-9, 2016.

5 Roland, A., Cucco, A., Ferrarin, C., Hsu, T.-W., Liau, J.-M., Ou, S.-H., Umgiesser, G., and Zanke, U.: On the development and verification of a 2-D coupled wave-current model on unstructured meshes, J. Mar. Syst., 78, S244-S254, 2009.

Rueda, A., Camus, P., Mendez, F. J., Tomas, A., and Luceno, A.: An extreme value model for maximum wave heights based on weather types, J. Geophys. Res-Oceans, 121, 1262-1273, doi: 10.1002/2015JC01095, 2016a.

Rueda, A., Camus, P., Tomas, A., Vitousek, S., and Mendez, F. J.: A multivariate extreme wave and storm surge climate emulator based on weather patterns. Ocean Modell., 104, 242-251, doi: 10.1016/j.ocemod.2016.06.008, 2016b.

Sallenger Jr, A. H., List, J. H., Gelfenbaum, G., Stumpf, R. P., and Hansen, M.: Large wave at Daytona Beach, Florida, explained as a squall-line surge, J. Coast. Res., 11, 1383-1388, 1995.

Serafin, K. A. and Ruggiero, P.: Simulating extreme total water levels using a time-dependent, extreme value approach, J. Geophys. Res-Oceans, 119, 6305-6329, doi: 10.1002/2014JC010093, 2014.

15 Socquet-Juglard, H., Dysthe, K., Trulsen, K., Krogstad, H. E., and Liu, J. D.: Probability distributions of surface gravity waves during spectral changes, J. Fluid Mech., 542, 195-216, doi: 10.1017/S0022112005006312, 2005.

Soomere, T.: Anisotropy of wind and wave regimes in the Baltic Proper, J. Sea Res., 49, 305-316, 2003.

Soomere, T.: Wind wave statistics in Tallinn Bay, Boreal Environ. Res., 10, 103-118, 2005.

Soomere, T., Myrberg, K., Leppäranta, M., and Nekrasov, A.: The progress in knowledge of physical oceanography of the

20 Gulf of Finland: a review for 1997-2007, Oceanologia, 50(3), 287-362, 2008.

Soomere, T., Eelsalu, M., Kurkin, A., and Rybin, A.: Separation of the Baltic Sea water level into daily and multi-weekly components, Cont. Shelf Res., 103, 23-32, doi:10.1016/j.csr.2015.04.018, 2015.

Stockdon, H. F., Holman, R. A., Howd, P. A., and Sallenger, A. H.: Empirical parameterization of setup, swash, and runup, Coast. Eng., 53, 573-588, 2006.

25 [SWAN]: SWAN Technical Documentation. Delft University of Technology. The Netherlands, 2007.

Tuomi, L., Kahma, K. K., and Pettersson, H.: Wave hindcast statistics in the seasonally ice-covered Baltic Sea, Boreal Environ. Res., 16, 451-472, 2011.

Tuomi, L., Kahma, K. K., and Fortelius, C.: Modelling fetch-limited wave growth from an irregular shoreline, J. Marine Syst., 105, 96-105, 2012.

30 Vilibic, I.: The role of the fundamental seiche in the Adriatic coastal floods, Cont. Shelf Res., 26, 206-216, doi: 10.1016/j.csr.2005.11.001, 2006 
Earth Syst. Dynam. Discuss., doi:10.5194/esd-2016-76, 2017

Manuscript under review for journal Earth Syst. Dynam.

Published: 31 January 2017

(c) Author(s) 2017. CC-BY 3.0 License.
Earth System

Dynamics

Discussions

(c) (i)

Vilibic, I., Monserrat, S., and Rabinovich, A.B.: Meteorological tsunamis on the US East Coast and in other regions of the World Ocean, Nat. Hazards, 74, 1-9, doi: 10.1007/s11069-014-1350-x, 2014.

Viška, M. and Soomere, T.: Simulated and observed reversals of wave-driven alongshore sediment transport at the eastern Baltic Sea coast, Baltica, 26 (2), 145-156, doi: 10.5200/baltica.2013.26.15, 2013.

5 Wadey, M. P., Brown, J. M., Haigh, I. D., Dolphin, T., and Wisse, P.: Assessment and comparison of extreme sea levels and waves during the 2013/14 storm season in two UK coastal regions, Nat. Hazards Earth Syst. Sci., 15, 2209-2225, doi: 10.5194/nhess-15-2209-2015, 2015.

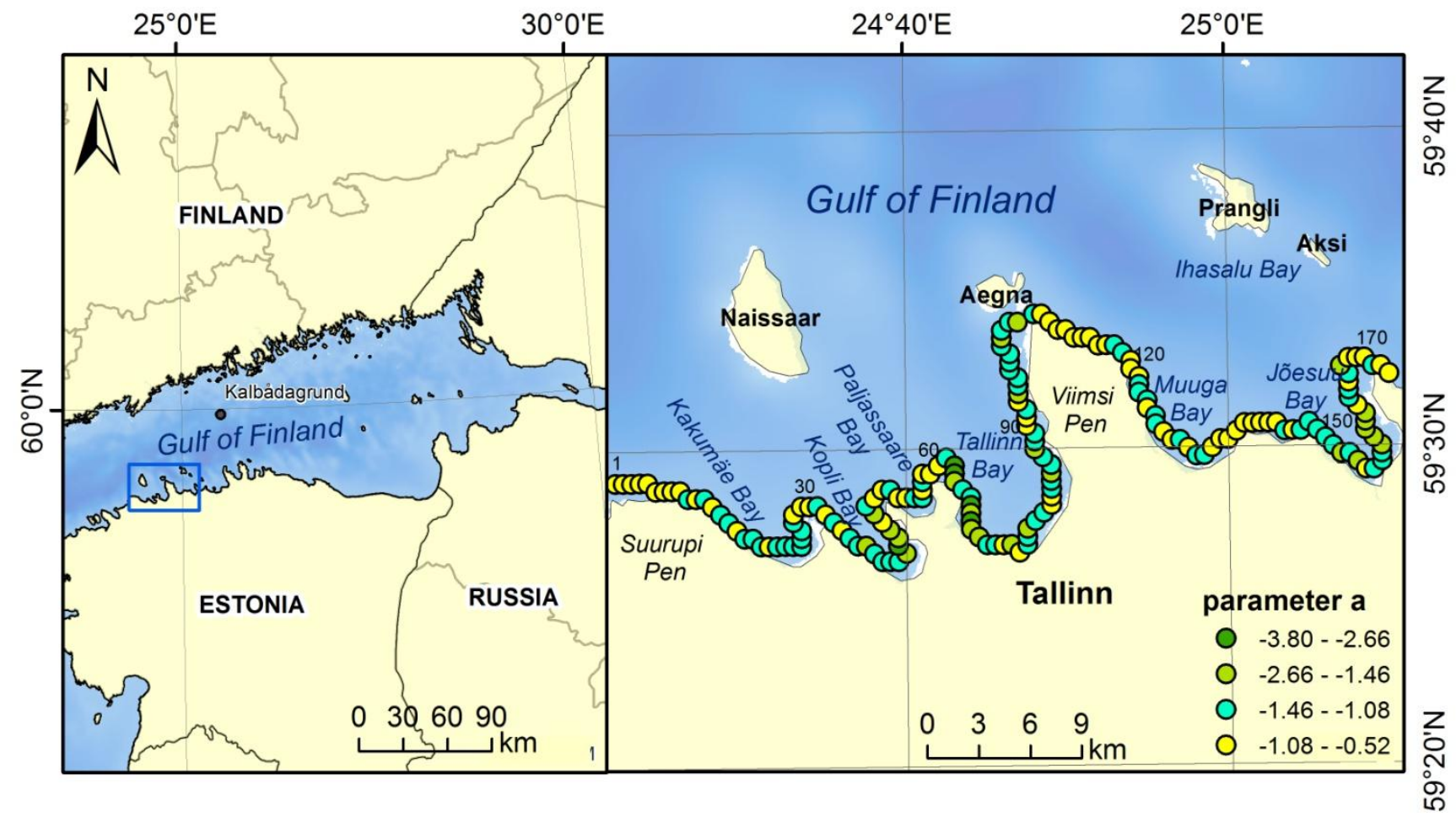

Figure 1: Study area in the vicinity of Tallinn Bay. Small circles along the shoreline indicate the nearshore grid cells of the wave model WAM with a resolution about $470 \mathrm{~m}$. Colour code indicates the coefficient at the leading term in the approximation of the exponent of empirical distribution of set-up heights in single locations. The selected grid cells are numbered consecutively from the west to the east. 
Earth Syst. Dynam. Discuss., doi:10.5194/esd-2016-76, 2017

Manuscript under review for journal Earth Syst. Dynam.

Published: 31 January 2017

(c) Author(s) 2017. CC-BY 3.0 License.

(c) (i)

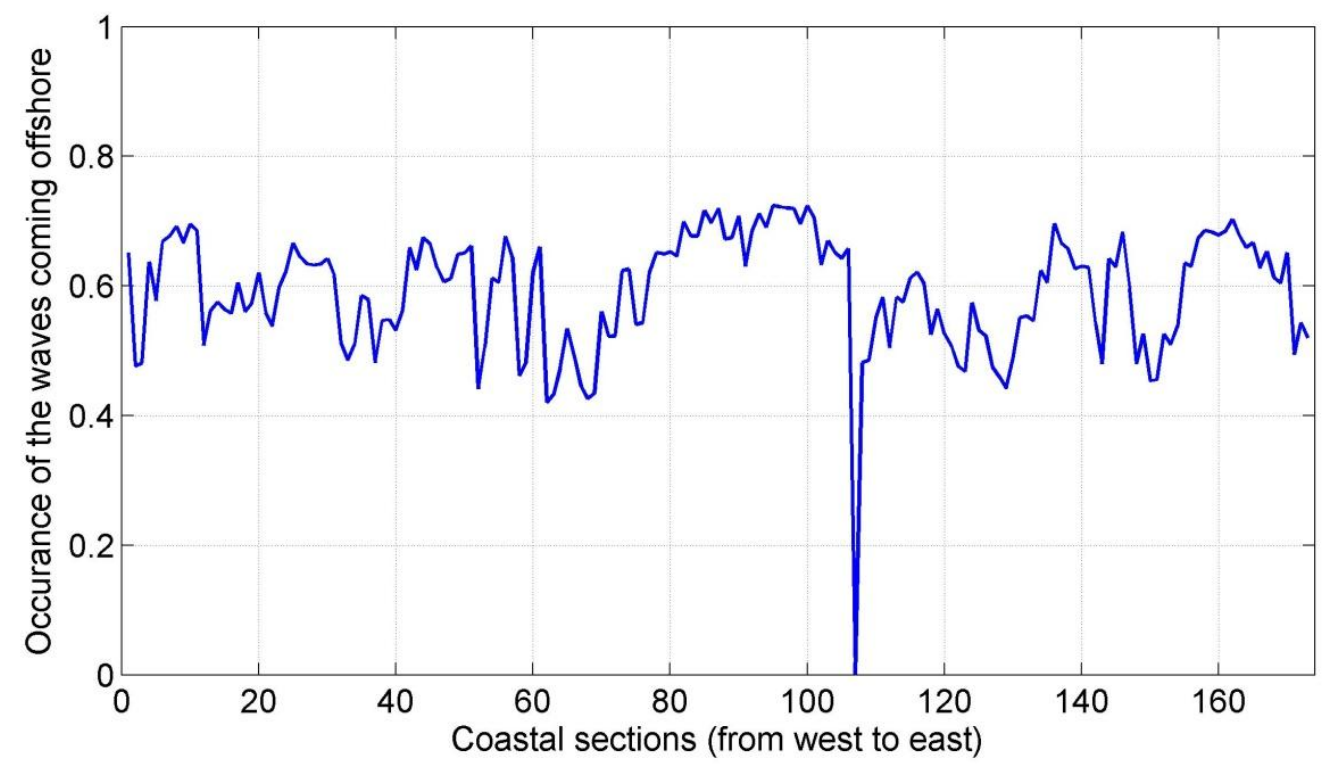

Figure 2: The percentage of occurrence of waves propagation onshore and producing elevated wave set-up events along the study area.

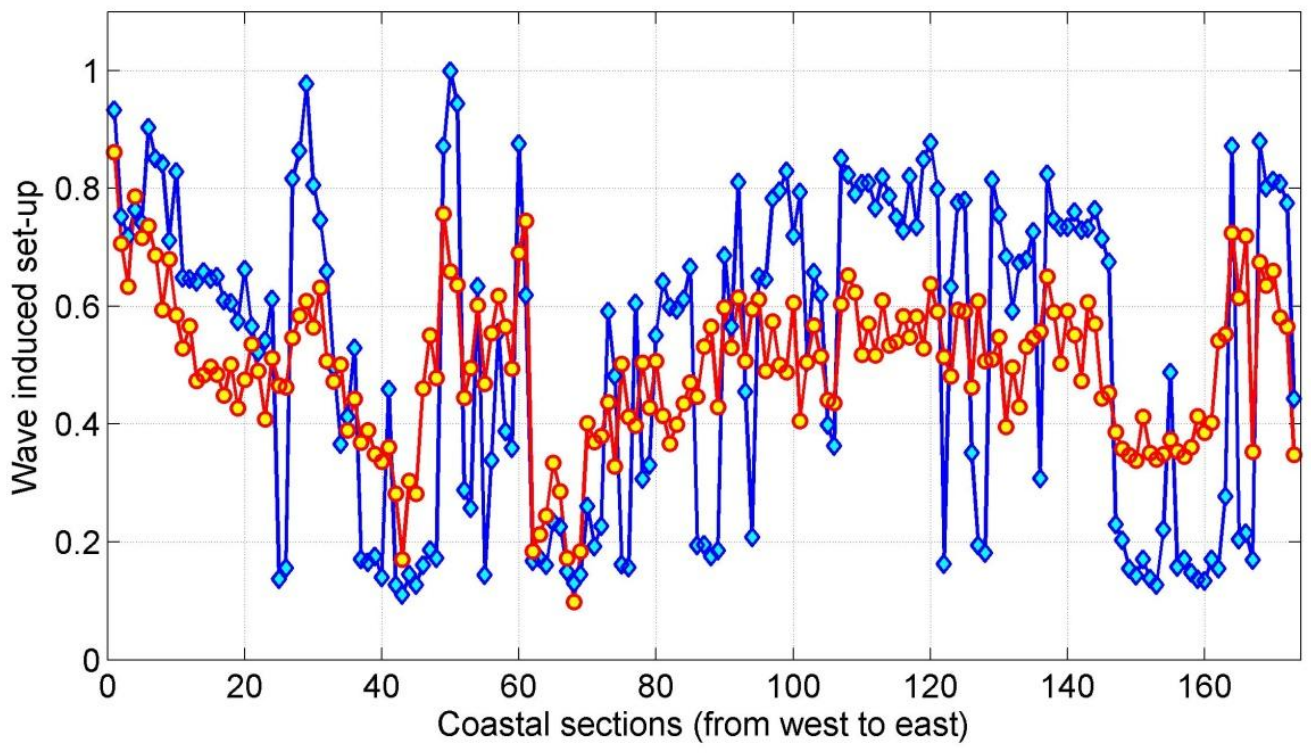

5 Figure 3: Maximum set-up heights evaluated using all onshore-propagating wave fields and Eqs. (1-8) (red circles) and similar heights evaluated using only these waves that approach the shore at an angle $\pm 15^{\circ}$ from the onshore normal (blue rhombi). 
Earth Syst. Dynam. Discuss., doi:10.5194/esd-2016-76, 2017

Manuscript under review for journal Earth Syst. Dynam.

Published: 31 January 2017

(c) Author(s) 2017. CC-BY 3.0 License.

(c) (1)
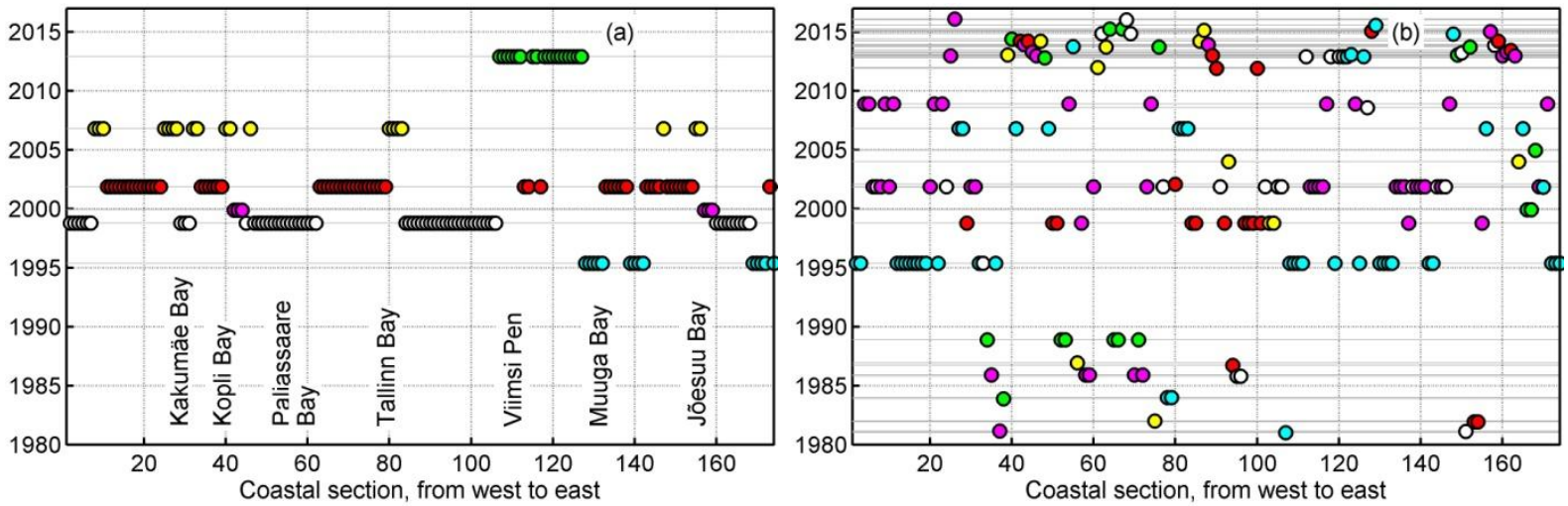

Figure 4: Six storms that caused the highest waves in different coastal sections of the study area in 1981-2016. Notice the cluster of green circles along the eastern coast of Viimsi Peninsula in an autumn storm of 2013 (b) 58 storms that caused the highest wave set-up in these sections in January 1981-May 2016. The set-up heights are evaluated similarly to the procedure in (Pindsoo and

Soomere, 2015) using only waves approaching at an angle $\pm 15^{\circ}$ with respect to the shore normal.
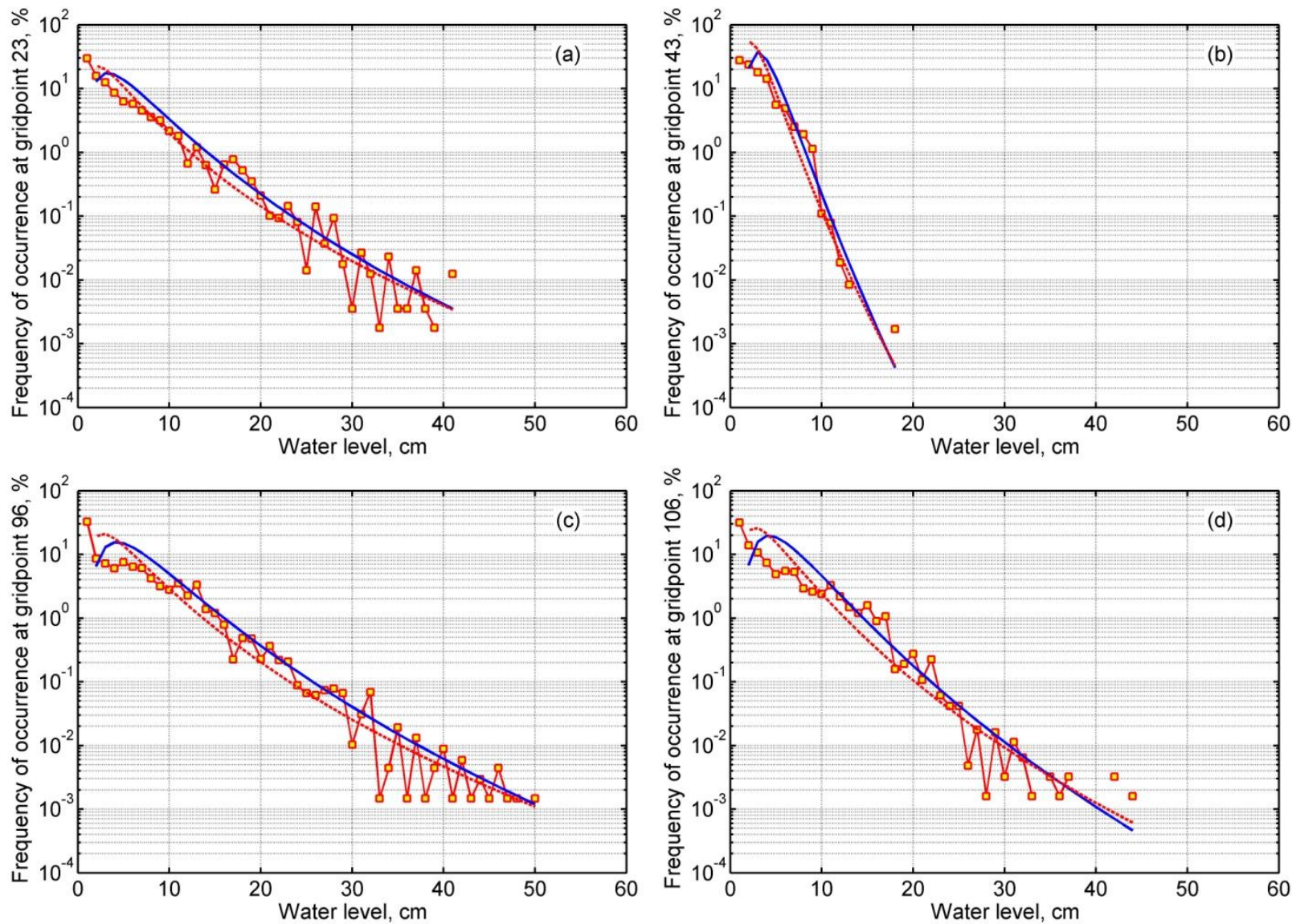
Earth Syst. Dynam. Discuss., doi:10.5194/esd-2016-76, 2017

Manuscript under review for journal Earth Syst. Dynam.

Published: 31 January 2017

(c) Author(s) 2017. CC-BY 3.0 License.
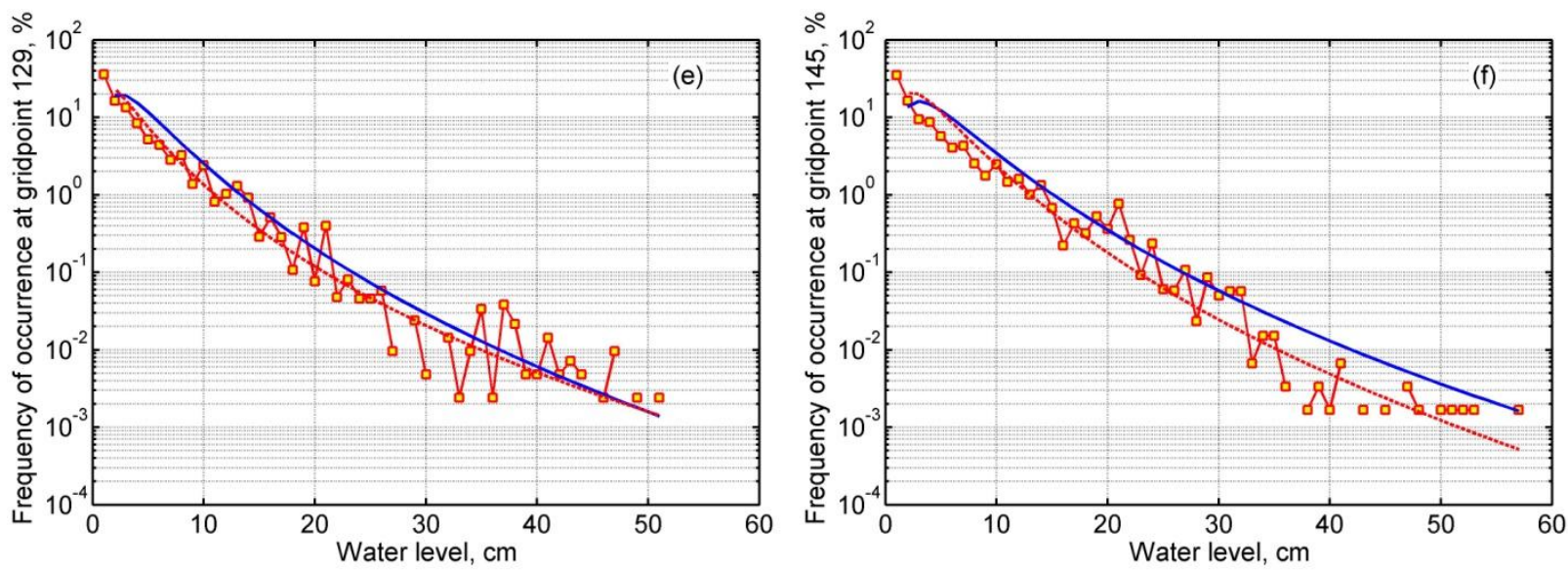

Figure 5: Simulated distributions of various set-up heights (red squares) at various locations of the Tallinn Bay area open to different directions. Blue line: interpolation with a quadratic function from the maximum of the distribution until the first gap at high set-up levels; red dashed line: similar interpolation using all data points.

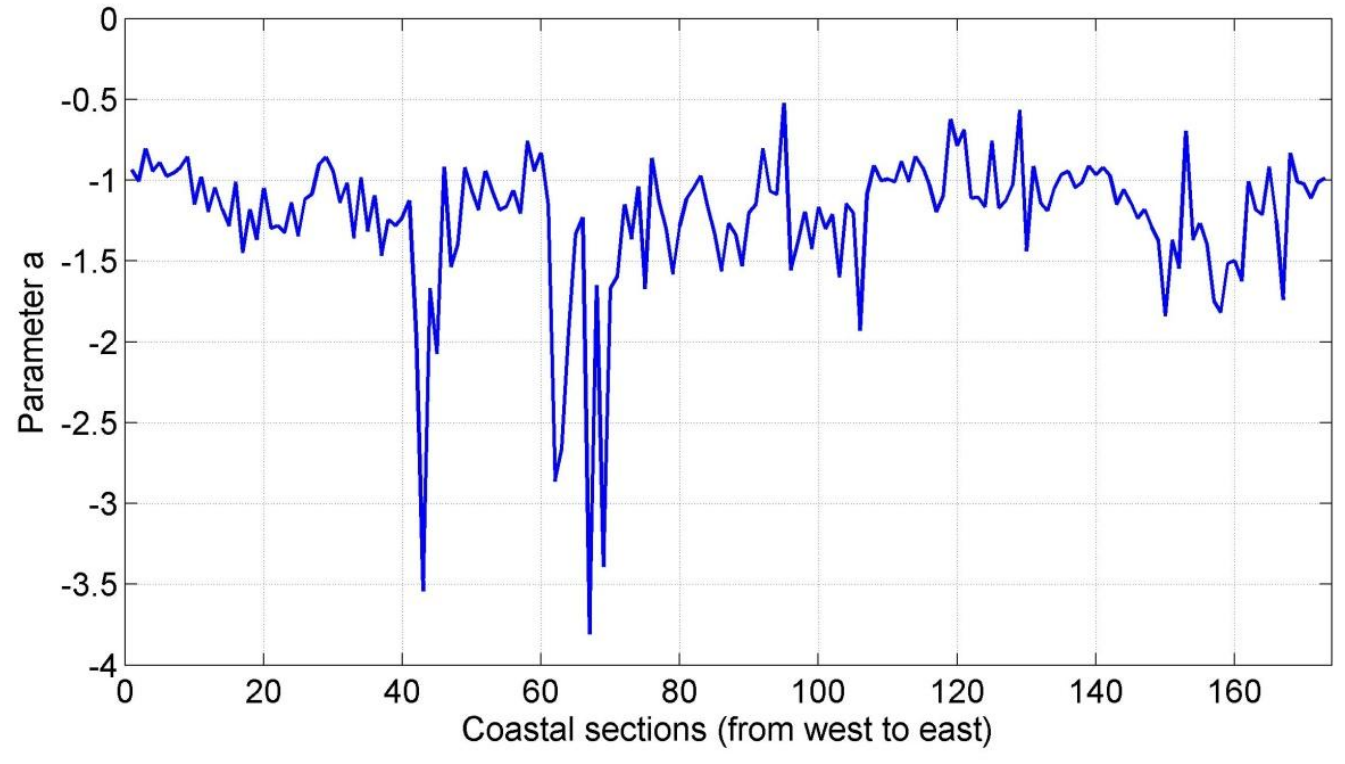


Earth Syst. Dynam. Discuss., doi:10.5194/esd-2016-76, 2017

Manuscript under review for journal Earth Syst. Dynam.

Published: 31 January 2017

(C) Author(s) 2017. CC-BY 3.0 License.
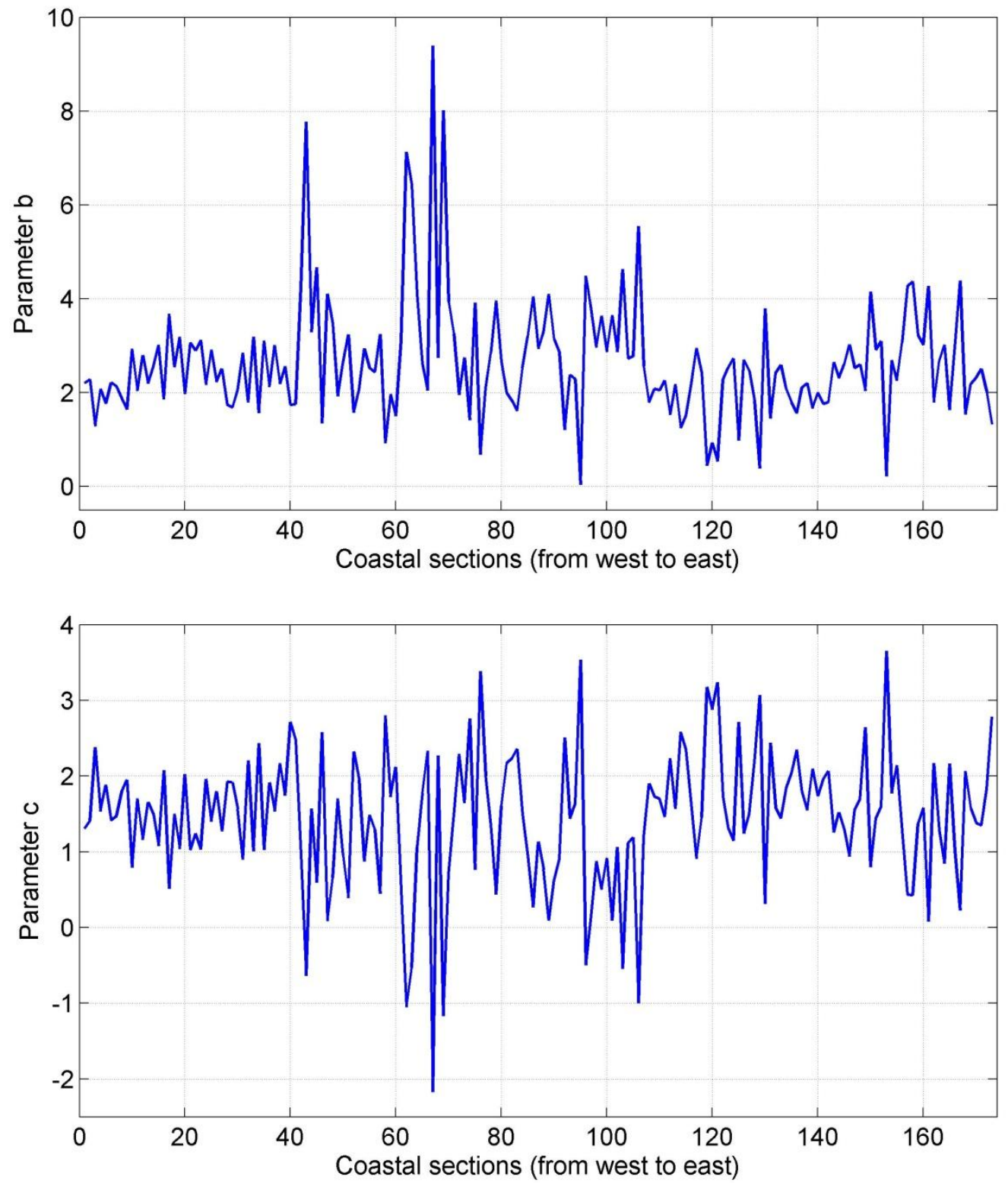

Figure 6: Alongshore variation of the coefficients $a, b, c$ of the quadratic approximation $a p^{2}+b p+c$ of the exponent of empirical distributions of set-up heights in the Tallinn Bay area. 